\title{
ON THE SUPPOSED OCCURRENCE OF SEEDLING INFECTION OF WHEAT BY MEANS OF RUSTED GRAINS
}

\author{
By W. L. WATERHOUSE, B.Sc., AGR., \\ Walter and Eliza Hall Research Fellow of the University of Sydney. \\ (Department of Plant Physiology and Pathology, Imperial College \\ of Science and Technology.)
}

AN important paper by Hungerford has recently appeared in the Jour. Ag. Research, vol. XIX. 15 June, 1920, p. 257, dealing with "Rust in Seed Wheat in Relation to Seedling Infection." As the result of careful and exhaustive experiments he states that, contrary to results reported by a number of previous workers, "stemrust (Puccinia graminis tritici, E. and H.) is not transmitted from one wheat crop to the next by means of infected seed grain. Further, in the writer's judgment, the occurrence of stemrust sori in the pericarp of the caryopses of grains and grasses has no especial significance, but the infection spreads to these tissues just as it does from an infection point in any of the vegetative parts of the plant" (p. 275).

The same writer gives a comprehensive summary of past work on this question and a full bibliography.

The present investigation was undertaken to see whether a histological examination of rusted grains during germination and the early stages of growth would throw any light on the problem. The results obtained confirm Hungerford's work and are briefly reported here.

In April, 1920, grain was obtained from a crop of wheat which was grown in Pembrokeshire in 1919 and badly rusted. Stubble left in the field was frequently found black with teleutosori, which were also abundant on awns, chaff and fragments of the rachis found mixed with the grain. The presence of teleutosori at the hilum end of a number of grains was determined and these grains were picked out. Several counts showed the percentage of rusted grain in the sample to vary from about 0.5 to 1.0 per cent. of the whole. The percentage of abnormal grains of a scabby nature was higher than this, and spores of the Fusarium and Helminthosporium type were obtained in scrapings from some of these. 


\title{
SOME PROBLEMS OF ECONOMIC BIOLOGY IN EAST AFRICA (KENYA COLONY)
}

\author{
By W. J. DOWSON, \\ Royal Horticultural Society's Gardens, Wisley. \\ (With 1 Text-figure.)

\section{INTRODUCTION.}

THE effect of meteorological conditions on the relations between the host and its parasites has received little attention at the hands of the pathologist, but in a country like East Africa it supplies the key to the solution of the problem concerning the severity of attack.

For an understanding of the problems which confront the economic botanist and the agricultural entomologist it is essential to gain some knowledge of the physiographical and climatic conditions of this part of Africa, conditions so varied in extremes as to affect both host and parasite to a marked degree. The Kenya Colony is situated between the 4th parallel $\mathrm{N}$. latitude and the 4th parallel $\mathrm{S}$. latitude, has an area nearly twice that of the United Kingdom, but a population which cannot amount to more than 5 millions. The equator passes through the northern slopes of Mount Kenya, the glacier-covered peak of which rises a few miles south to a height of 17,000 odd feet. 120 miles due south of Kenya and just within Tanganyika Territory is Mount Kilimanjaro, whose summit rises 19,000 odd feet above sea level; and 120 miles W.N.W. from Kenya, and on the boundary line separating Uganda from East Africa lies Mount Elgon, 14,000 feet in height. The snow line is situated at an altitude of 15,000 feet above sea level.

These numbers are apt to give an exaggerated impression of altitude, for the height of all the Central African mountains from the general level of the surrounding country is considerably less because they rise from plateaux and uplands of 5000 to 7000 feet. Thus the highest point of Kenya from the general level of the surrounding country is, roughly, 11,000 feet.

Running north and south right through the country is the Great Rift Valley, one branch of which stretches from Lake Rudolph in the north 


\section{Problems of Economic Biology in East Africa}

to Kilimanjaro in the south. This is the shorter arm of the Great Rift; the other, and longer, passes to the westward and embraces lakes Tanganyika and Nyassa.

The Uganda Railway crosses the Rift Valley at an angle and at the point where it crosses the two escarpments, the western or Mau escarpment is slightly higher ( 8320 feet) than the eastern or Kikuyu escarpment which is just under 8000 feet (see vertical diagram). Along the western rim of the escarpment between latitude 0 and $1 \mathrm{~S}$. lies the Aberdare range which runs for a distance of 30 miles due north and south, and attains a height of 13,000 feet. The average height of the two escarpments is between 2000 and 3000 feet above the floor of the valley, itself some 6000 to 7000 feet above sea level, where it is crossed by the railway. The drop is always steep and in some places almost precipitous. It will be seen from the diagram that the land rises rapidly from the coast and that

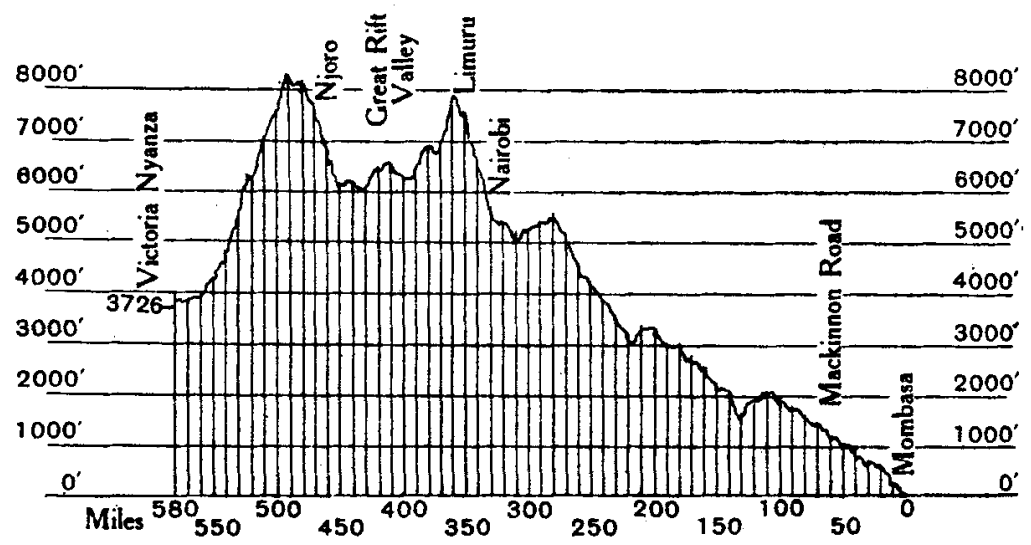

Fig. 1. Vertical diagram of Uganda Railway.

a comparatively short distance along the railway in the direction of Victoria Nyanza the altitude increases very considerably. The meteorological conditions along the course of the railway are very varied. Thus at Mombasa the annual rainfall is between 60 and 70 inches, but 60 miles inland, at Mackinnon Road Station (1300 feet) the average fall is not much more than 10 inches. Again Nairobi (5500 feet) has an annual rainfall of 30 inches, but 25 miles farther along the line Limuru ( 7500 feet) records an average rainfall of 70 inches. The different climatic conditions at these two places as a result of altitude are remarkable and exert a marked influence upon the spread of fungous diseases.

It is proposed to discuss shortly the most important problems of the 
economic biologist, and to consider each plant or crop in the order which one naturally comes across it when travelling on the Uganda Railway from Mombasa to the Victoria Nyanza.

The writer wishes to acknowledge his indebtedness to the Entomological Division of the Agricultural Department at Nairobi for the knowledge acquired concerning insect pests.

\section{The Cocoanut Palm.}

The rainfall along the coastal belt is between 60 and 70 inches, but towards the S.E. corner in the neighbourhood of Shimoni the rainfall is greater, and besides such indigenous palms as Hyphaene thebaica, Borassus flabellifer and Cocos nucifer, a small patch of the oil palm Elaeis guineensis occurs. The rains are distributed in two seasons, a short one in November and a longer period from April to June. Along this coastal strip and for about 20 miles inland cocoanut palms are grown in plantations owned by Swahilis, Arabs, Indians and Europeans. The palms are subject to numerous diseases and pests, the most important of which are undoubtedly the bud-rot or heart-rot, and the cocoanut beetle (Oryctes monoceros). In the first, the infection can be traced from the upper external portion of the youngest folded leaf, but whether primarily due to Phytophthora palmivora Butl. or to bacteria was not ascertained. The dried and wilted upper portion of the spear contained much mycelium, but towards the actual rotting margin no hyphae were discovered.

Unlike most countries in which bud-rot has been recorded, the palm in East Africa is attacked at the bearing age, seven years, and very considerable loss is thereby caused to owners of large plantations in which several hundreds of acres have been planted out at one time. To the north of Mombasa, on an extensive plantation in which African and Ceylon nuts had been planted, 60 per cent. of the young Ceylon palms were attacked and killed in three years, and so susceptible did these imported palms prove that the rest were taken out and replaced with sisal hemp. The African palms appeared much more resistant, thus indicating that the disease, as it exists in East Africa, is probably native to that country, and has not been imported. Besides the high susceptibility of imported palms and the comparative resistance of native palms, three other points are worthy of notice. One is the striking fact that palms are only found in certain places and have never been known to thrive in others. Thus along the coast south of Mombasa on the Gazi Road, palms grow in patches which alternate with strips of country apparently similar in all other respects but upon which there are no palms. 
The palm patches are mostly cultivated, are owned by natives, and alternate with areas of bush, forest or grass. The oldest natives in the district state that their ancestors tried to grow cocoanuts on these places but invariably failed. It is usually only these palmless areas which can be acquired, and in a number of instances it has been found that the cocoanut will not thrive in such.

On the other hand it has frequently happened with plantations of a permanent crop such as cocoanuts, coffee and citrus, that the first European holder of the land, in order to save time and expense, and to ensure a "quick return," has hastily ploughed and planted with immature seed or weak plants. These grow for a time according to circumstances, and to the new-comer, who is looking for a plantation already laid out, they appear in good condition. The original holder sells his plantation at a handsome profit on his outlay and is heard of no more. It is usually later when the crop should be bearing that serious trouble commences, and such cases are some of the most difficult with which the economic biologist is confronted.

The third point which is important in any consideration of the bud-rot disease is the state of cultivation in which the plantation is kept. On a certain plantation in which bud-rot had been recorded since 1912, those palms in the camp for native labour were not only of greater size and of more healthy appearance than those in the plantation, but in addition bore fruit earlier (5-6 years) and never showed a sign of the disease. It was only among the palms outside of the encampment that the disease appeared. These had been planted at the same season, and the only obvious difference between them was in their subsequent treatment. The camp had been kept scrupulously clean, no growth between the huts, and therefore between the palms, was allowed, and rubbish which might collect from food was never left lying about. On the other hand, but a few yards away from the camp, the ground was only weeded occasionally, as the supply of labour allowed, and then only between the palms and not underneath them. The idea seemed to prevail that hoeing up grass and weeds from the spaces between the palms and putting this to rot on top of the weeds growing at the foot of each tree, would produce excellent tilth. In reality, this procedure gave rise to the formation of the most favourable breeding-ground for all manner of fungi and insects -not to mention the non-aeration of the root system.

Among insect enemies, mention must be made of the rhinoceros beetle (Oryctes monoceros 0 liv.). This large beetle, nearly 2 inches long, flies mostly at night and feeds on the tender tissues of the youngest 
unfolded leaf. The edge of the leaf is not eaten away but a cylindrical hole is esten out, the diameter of the beetle's body, from one side to the innermost soft tissues, passing through esch leaflet in turn. Consequently, when the leaf unfolds a circular rent appears in each leaflet, the line of holes being nearly straight. Very often the beetle manages to bore through the midrib, in which case the end of the loaf falls over and rots away. The pest can be so bad that nearly all the leaves present these lines of holes with a number of the tips fallen over. Occasionally the beetle eats the hole near enough to the growing point of the palm as to be the means of starting a heart-rot which in its effects upon the palm is similar to the bud-rot.

Effective measures of controlling this pest were only devised after the life-history of the beetle had been discovered. The female beetle lays her eggs irrold rotting stumps of the cocoanut palm or other trees in the vicinity. Hence the idea arose of making beetle egg traps and, as the results have shown, these have proved fairly successful if regularly inspected. The traps are made by collecting all the old stumps and decaying vegetation and packing them in pits in the neighbourhood of the palms. The pits are roughly 2 feet deep and 10 foet acrous. It is important to destroy all the rest of the rotting stumps and vegetation not used in the construction of the traps, which would be used by the beetles to lay their eggs. At regular intervals the traps are inspected; and when found to contain a goodly number of larvae, a covering of sand is placed over them and carbon bisulphide is injected into each, thus killing the larvae.

\section{Bigar Hricp.}

Besides the cocosnut palm, sisal hemp, Agave rigida, var. sisalama, is also grown in extensive plantations along the coastal belt. This plant has borne in the past the reputation of being the only crop in East Africa which possessed no enemies. Bisal was first introduced in $\mathbf{1 8 9 5}$ in the form of bulbils from Yucatan by the Germans into German. Feast Africa (now Tanganyika Territory).

In the extremely dry conditions of Yucatan the plant growe for twenty or more years before produaing its single inflorescence, after which it dies down. Owing to this slow growth but few leaves are formed each year, and hence only a few can be cut annually from each plant for the decortication of the fibre. In Yucatan it is possible to make use of the waste which is washed away by a stream of water and which contains a considerable amount of sugar. The liquid is filtered and fermented to produce a strong alooholic drink. 
unfolded leaf. The edge of the leaf is not eaten away but a cylindrical hole is eaten out, the diameter of the beetle's body, from one side to the innermost soft tissues, passing through eroh leaflet in turn. Consequently, when the leaf unfolds a circular rent appears in each leaflet, the line of holes being nearly straight. Very often the beetle manages to bore through the midrib, in which case the end of the leaf falls over and rots away. The pest can be so bad that nearly all the leaves present these lines of holes with a number of the tips fallen over. Occasionally the beetle eats the hole near enough to the growing point of the palm as to be the means of starting a heart-rot which in its effects upon the palm is similar to the bud-rot.

Effective measures of controlling this pest were only devised after the life-history of the beetle had been discovered. The female beetle lays her eggs irr old rotting stumps of the cocosnat palm or other trees in the vicinity. Hence the idea arose of making beetle egg traps and, as the results have shown, these have proved fairly succesaful if regularly inspected. The traps are made by collecting all the old stumps and decaying regetation and packing them in pits in the neighbourhood of the palms. The pits are roughly 2 feet deep and 10 feet acroes. It is important to destroy all the rest of the rotting stumps and vegetation not used in the construction of the traps, which would be used by the beetles to lay their eggs. At regular intervals the traps are inspectod; and when found to contain a goodly number of larvae, a covering of sand is placed over them and carbon bisulphide is injected into each, thus killing the larvae.

\section{Sisal Herux.}

Besides the cocoanut palm, sisal hemp, Agare rigida, var. visalana, is also grown in extensive plantations along the coastal belt. This plant has borne in the past the reputation of being the only crop in East Africe which possessed no enemies. Bisal was first introduced in 1895 in the form of bulbils from Yncatan by the Germans into German. Enast Africa (now Tanganyika Territory).

In the extremely dry conditions of Yucatan the plant grow for twenty or more years before producing its single inflorescenoe, after which it dies down. Owing to this slow growth but few leaves are formed each year, and hence only a few can be cut annually from each plant for the decortication of the fibre. In Yucatan it is possible to malre use of the waste which is washed away by a stream of water and which contains a considerable amount of sugar. The liquid is filtered and fermented to produce a strong alooholic drink. 
Number of districts

\begin{tabular}{ccccccc}
$\begin{array}{c}\text { with indices } \\
\text { " }\end{array}$ & 1,2 , or 3 & 11 & 8 & 7 & 4 & 3 \\
" & 4,6 , or 6 & - & 3 & 4 & 7 & 2 \\
Total number of districts & 7,8 , or 9 & - & - & - & - & 3 \\
\hline To or more & - & - & - & - & 3 \\
\hline
\end{tabular}

$\begin{array}{ccccc}1913 & 1913 & 1914 & 1914 & 1914 \\ \text { Brood I } & \text { Brood II } & \text { Brood I } & \text { Brood II } & \text { Brood III }\end{array}$

At Garforth the progress was more rapid. The indices were:

$\begin{array}{lll}1913 & \text { Brood I } & 2 \\ 1913 & \text { Brood II } & \text { No survey } \\ 1914 & \text { Brood I } & 22 \\ 1914 & \text { Brood II } & 32 \\ 1914 & \text { Brood III } & 76\end{array}$

3. In the East Riding area the indices are on the whole higher in the northern part of the area than in the southern. If we divide the whole area into two parts, a northern part containing districts I, II, III, IV, V, and VI, and a southern part containing districts VII, VIII, IX, $X$, and $\mathrm{XI}$, and calculate for each survey the average percentages of attacked plants in the fields of these two parts, we get the following figures:

$\begin{array}{llcccc}\text { Survey } & \begin{array}{c}\text { Number of fields } \\ \text { examined }\end{array} & \begin{array}{c}\text { Average } \\ \% \text { CL }\end{array} & \begin{array}{c}\text { Number of fields } \\ \text { examined }\end{array} & \begin{array}{c}\text { Average } \\ \% \text { CL }\end{array} \\ 1913 \text { Brood I } & 75 & 1 \cdot 3 & 76 & 0 \cdot 8 \\ 1913 \text { Brood II } & 75 & 2 \cdot 7 & 76 & 2 \cdot 8 \\ 1914 \text { Brood I } & 80 & 3 \cdot 1 & 109 & 1 \cdot 6 \\ 1914 \text { Brood II } & 80 & 4 \cdot 3 & 109 & 2 \cdot 4 \\ 1914 \text { Brood III } & 80 & 9 \cdot 7 & 109 & 4 \cdot 0\end{array}$

4. The coast districts in the East Riding area have on the whole distinctly lower indices than the inland districts. On dividing the area into a coast region, including districts $I, I I, I I I$, and $X$, and an inland region, including districts $I V, V$, VI, VII, VIII, IX, and XI, and finding the average percentage of attacked plants in the fields of these two regions, we get the following figures:

\begin{tabular}{|c|c|c|c|c|}
\hline \multirow[b]{2}{*}{ Survey } & \multicolumn{2}{|c|}{ Coast region } & \multicolumn{2}{|c|}{ Inland region } \\
\hline & $\begin{array}{c}\text { Number of fielde } \\
\text { examined }\end{array}$ & $\begin{array}{l}\text { Average } \\
\% \mathrm{CL}\end{array}$ & $\begin{array}{l}\text { Number of fields } \\
\text { examined }\end{array}$ & $\begin{array}{l}\text { Average } \\
\% \mathrm{CL}\end{array}$ \\
\hline 1913 Brood I & $\mathbf{5 3}$ & I-1 & 98 & 1.2 \\
\hline 1913 Brood II & 63 & $1 \cdot 4$ & 98 & $3 \cdot 5$ \\
\hline 1914 Brood I & 52 & 1.8 & 137 & $2 \cdot 3$ \\
\hline 1914 Brood II & 52 & 1.9 & 137 & $3 \cdot 7$ \\
\hline 1914 Brood III & 52 & $3 \cdot 2$ & 137 & $7 \cdot 6$ \\
\hline
\end{tabular}


much more slowly in the dry season. Both C. arabica and $C$. nandiensis are subject to a number of fungous and insect enemies. Meteorological conditions play a most important part in the severity of attack of both fungi and insects, particularly so in the coffee leaf disease due to the Iust Hemileia vastatrix B. \& Br.

So far as the writer is aware, coffee cultivation in the eastern hemisphere, including Africa, has always been intimately connected with that of Hemileia, and has usually resulted in the ascendancy of the parasite sooner or later. This does not necessarily mean that the coffee trees are threatened with destruction as was the case in Ceylon, but it does mean that Hemileia is slowly spreading in all those countries in which coffee is grown, with the present exception of the highlands of East Africa.

It is hoped to deal with the subject of coffee leaf disease in Central and Eastern Africa in more detail in a further paper. For the present purpose, some observations of the disease as it is now found in the highlands of Kenya Colony will suffice.

The first observation of importance is that only once in Africa and in Ceylon have the teleutospores of the parasite been found. It is a curious and as yet an unexplained fact that since Marshall Ward worked out the life-history of the fungus in Ceylon, and a German observer reported the presence of teleutospores on some African specimens of the disease not long afterwards, these spores have never been observed since. The likelihood, therefore, of the existence of an aecidial stage on some other plant is not very great. Coffee leaf disease, like many other rusts, is propagated in the countries in which it is found by the uredospores only.

The second observation to be recorded is, that the first attack of Hemileia is undoubtedly the most severe; subsequent attacks, other things being equal, are less marked in intensity. Nearly all the trees are badly infected, but in well-kept plantations only a small percentage of the leaves actually fall, although the lives of the others are considerably curtailed. Entire defoliation never takes place, and subsequent attacks are less severe, that is to say, not so many pustules of uredo-sori are formed and not so many leaves are infected. That the general health of the trees has much to do with the severity of the attack is obvious when an ill-kept plantation is compared with others better cared for in the vicinity at any season of the year. The initial preparation of the ground, the proper planting of the seedlings, pruning and the amount of berries the trees are allowed to carry, are all factors which influence the resistance of the host. 
The third and perhaps most important observation is the effect of altitude and, therefore, of temperature both on the tree and on Hemileia. At the Mission Station of Bura near the coast, at an altitude of nearly 2000 feet, the annual rainfall is about 50 inches and the temperature about $75-80^{\circ} \mathrm{F}$. both day and night. The atmosphere is therefore warm and moist, conditions favourable to the luxuriant growth of coffee, but much more so to Hemileia rastutrix which has destroyed the coffee plantstion attached to the Mission. In the neighbourhood of Nairobi the general altitude of the plantations lies between 5000 feet and 6000 feet, and the rainfall of the district averages 30 inches. The atmosphere is therefore dry, although it is to be noted that very heavy dews are precipitated at night, and it is in this dew that the uredospores usually germinate. The temperature is never very high, and rarely exceeds $75^{\circ} \mathrm{F}$., droppinf again at night to the region of $50-40^{\circ} \mathrm{F}$. and sometimes lower. The atmospheric conditions are warm but not moist and the general balance of conditions is less favourable to the spread of Hemileia than to the growtt of coffee. Ten miles to the north-west of Nairobi in the Limuru distric very different conditions prevail. The altitude is greater, between 600 and 7000 feet, and hence the climate is colder on the whole. On the othe: hand, the rainfall is much greater, averaging between 60 and 70 inchea The atmosphere is saturated in the mornings and a "Scotch mist" is th normal experience. The climatic conditions at Limuru, therefore, are th reverse of those 10 miles away, and a moist but comparatively colde atmosphere prevails. Coffee under these conditions is not so luxurian in growth, is slower but mpre hardy. Hemileia is prevalent throughou the district but is scarce; the first attack is the worst as is the case a lower altitudes, but it is nothing like so severe, and in well-kept plants tions in a normal season the rust has to be searched for.

The conditions then which prevail at altitudes of 6000 to 7000 fee are still favourable to coffee but very much less so to Hemileia an the limiting factor to the rapid spread of the disease is temperatur At such altitudos the temperature is too low for the parasite 1 flourish.

It has been pointed out that subsequent attacks of the rust are le severe than the first, which means that the coffee trees acquire a certa: power of resistance, or become less susceptible after the initial attac That this partial immunity is not due to a lessening of the virulence the parasite is demonstrated by the fact that a hitherto nnattack plantation in the vicinity of others which have been already visited much more severely infected when $H$ emileia is present on all at the sar 
time. The virulence of the fungus remains the same, the resistance of the host increases.

Under such conditions, spraying for leaf disease has proved successful at altitudes of 5000 to 7000 feet. Any dilute fungicide has been found by experiment not only to control the disease but, if applied at the right time, to completely eradicate it from plantations. The usual time for spraying is just before the long rains commence, and again at their termination. Reinfection usually takes place in subsequent seasons by reason of wind-blown uredospores from a plantation which has not been sprayed. In the Limuru district the disease does such little damage that spraying, always an expensive business, has not been resorted to. The most popular fungicide, and one easily made up, is known locally as "carbide," and is prepared by adding 12 ozs. of calcium carbide to 40 gallons of a solution containing $2 \mathrm{lbs}$. of copper sulphate in water. At lower altitudes, e.g. between 4000 and 5000 feet, spraying with such dilute fungicides is of no avail; but with a stronger mixture containing 4 lbs. of copper sulphate and 24 ozs. of calcium carbide per 40 gallons, the results are much more encouraging, particularly on well-cultivated plantations. At such altitudes it is essential to spray regularly to keep -Hemileia in check. Below 4000 feet, if the rainfall is at all suitable for the growing of coffee, the other factor of temperature is so much more favourable to the rapid spread of Hemileia that the disease cannot be controlled by any known method, and on account of this, coffee growing is rendered unprofitable at such altitudes.

Of other fungous diseases of coffee; mention may be made of the leaf and berry spot due to the attacks of Cercospora coffeicola B. \& Cke. Considerable damage has been caused by this fungus on neglected plantations, and cases have occurred in which defoliation has resulted. On the berries it is rather more serious from the planter's point of view, as the affected fruits cannot be pulped clean. This trouble is more prevalent during unusually heavy and prolonged rains but can always be found on ill-cared for plantations either on the leaves at any time, or on the berries as they commence to turn red. The disease is easily controlled by spraying either with the "carbide" mixture mentioned above, or with Bordeaux mixture containing $2 \mathrm{lbs}$. of copper sulphate per 40 gallons.

Quite recently a berry spot has occurred due to infection by a species of Septoria, which in its effects on the fruit is similar to that produced by Cercospora coffeicola, but it is not known whether this species is identical with $S$. maculosa (Berk.) Cke. recorded on coffee berries from Venezuela. The disease is more common on low lying heavy soil, and is 
(Brood II) is plotted for various rows in Field $\mathbf{K}$ at Driffield, sown June, last week, which was next to Field L, sown June, first week, which was attacked by the first brood of the Midge. The two lots of swedes were separated by a hedge and about thirty yards of barley. The graph shows a very marked drop in the percentage of plants attacked in Field $K$ as the distance from Field $L$ increased.

In 1914 the evidence of such movement was not so clear.

(c) Factors determining the Swede Midge index in different districts.

The indices for each district in each survey are given in Tables 2 and 3 , and plotted on Charts 1 to 5. On the charts for the Brood II and Brood III surveys I have also shown in which districts the index exceeded the index of the previous survey and in which districts the index was not greater. In Chart 5 the indices are the highest and the differences between the various districts are greatest.

The two factors which seem to be most important are:

(1) Average date of sowing,

(2) Distance from the sea.

(1) Average date of sowing.

In the northern part of my East Riding area, as I have shown (p. 88), the Midge is more numerous than in the southern part, and a glance at the charts will emphasize this fact. Mr Henry Ullyott, C.C., farmer and agricultural valuer, has kindly provided me with what in his experience are the average sowing dates for these two parts of my area. For each of the districts in the northern part the estimate which he gives is the last week in May; for all those in the southern part, the first week in June. In my survey work I examined fields just as I came to them, and the numbers of May sown and June sown fields which I visited in the northern and southern parts are as follows:

\begin{tabular}{|c|c|c|c|c|}
\hline & \multicolumn{2}{|c|}{1913} & \multicolumn{2}{|c|}{1914} \\
\hline & $\begin{array}{l}\text { Number of May } \\
\text { sown fields }\end{array}$ & $\begin{array}{c}\text { Number of June } \\
\text { sown fields }\end{array}$ & $\begin{array}{c}\text { Number of May } \\
\text { sown fields }\end{array}$ & $\begin{array}{l}\text { Number of June } \\
\text { sown fields }\end{array}$ \\
\hline orthern part & $\mathbf{6 2}$ & 23 & 69 & 11 \\
\hline onthern part & 27 & 49 & 55 & 54 \\
\hline
\end{tabular}

In 1914, Mr Ullyott tells me, sowing was earlier than usual throughout the East Riding area. At Garforth, where the Midge is more numerous than in the East Riding, sowing is earlier. The average date there is the third week of May. Neither in 1913 nor 1914 did I come across any fields sown later than the last week in May.

I have already shown that May sown fields are worse attacked than 
ditions, the suddenness of the withering, the rapid disorganising of the cortical tissues and the presence of the three parasitic fungi mentioned above.

The insect pests of coffee are more serious than are the parasitic fungi, and mention may be made of at least two which have been computed to cause more annual loss than perhaps any other disease to which coffee is subject. The variegated bug, Antestia lineaticollis Stäl, has been known almost from the commencement of ccffee planting throughout Africa. The insect punctures all the young growing parts of the tree, but chiefly the very young flower buds which are formed in whorls in the axils of the leaves. The result is a non-formation of flowers and a proliferation of shoots in their place, thus bringing about an almost total failure to set fruit and causing much additional labour and expense in pruning. Antestia also pierces and sucks the green berries producing a stain upon the kernels which considerably lessens their market value. As is usual with such insects, spraying either with a stomach poison or a contact insecticide is of no avail. The bug is active and either hides under leaves and crevices, or flies to the ground where it becomes invisible owing to its colour. In the past the usual method of combating this pest was the collecting by hand of the bugs, but recent knowledge of the lifehistory has indicated a more effective way of controlling the numbers of the insect. The eggs are laid in clusters of a dozen on the underside of the leaves and are normally pearly white in colour. A large number of eggs are not white but grey, and out of these hatch out, not young Antestia bugs but minute chalcids. Two species of these have been discovered which parasitise the eggs of Antestia, and it has been found possible on the Government Experimental Farm near Nairobi to breed the parasites in the laboratory in such numbers as to completely check the inerease of Antestia. It is hoped in time to be able to distribute the parasite early enough to those plantations which show signs of the pest to prevent the insect from doing appreciable harm.

Another serious insect pest is comparatively new, having first made its appearance in 1915, and is a species of Diathrothrips (D. coffeae Will.). This minute insect appeared in the dry season of 1915 in clouds, and, settling upon the coffee trees of a plantation close to Nairobi, sucked every green part almost dry, produoing a conspicuous silvery appearance of the foliage. The trees were entirely defoliated, and in some instances killed. From the Nairobi area the pest gradually spread in a north westerly. direction and is approaching Uganda. As in the case of Antestia, no known spraying fluid is of the least avail, for at the first contact of an 


\section{P'roblems of Economic Biology in East Africa}

insecticide the great majority of insects fly into the air and hover over the trees in a cloud. They cannot, however, stand heavy rains, and shortly after these commence the pest disappears. The insect appears in very large numbers only in a prolonged dry season and then reigns supreme until the next rains clear it off again. Where it originally came from, its life-history, and what becomes of it during the rains, are problems still awaiting solution.

A third pest, which is often responsible for a large amount of replanting, is the cut-worm, a larva of various species of the moths Agrotis and Euxoa. E. segetum is the most common. Newly planted out seedlings are very subject to attack and are girdled just below ground level. Gathering by hand, and the protection of the young stem by a band of some durable substance soaked in grease, are the methods employed in controlling this pest. Baits of chopped grass sprinkled with Paris Green have not proved very effective.

The remarks relating to the sound cultivation of the cocoanut palm are equally applicable to coffee and indeed to any permanent crop.

Finally, as regards coffee, it is a point of considerable interest to compare the yield of the East African crop with that of other countries of the East. In the best days of Ceylon coffee the heaviest yield was not more than $\frac{1}{2}$ ton to the acre, and the average was rather below this. In East Africa the average yield is greater; over a ton has been recorded more than once, and $\frac{3}{4}$ ton to the acre is not considered an excessively heavy crop. Latterly, however, it has been found by experience that the trees do better, are not so exhausted and are therefore more capable of withstanding disease, if the crop is limited to not more than $\frac{1}{2}$ ton to the acre. This can be done by stripping off some of the young fruits soon after they have set.

\section{The Forests of the Highlands.}

The forest areas of East Africa are not very numerous but are of considerable extent, the most important for valuable timber being those of the Highlands at altitudes ranging from 6000 to 8000 feet. Of the many different trees which yield good timber only a few are used at present to any great extent. The yellow wood, Podocarpus gracilior, and the so-called East African Cedar, Juniperus procera, are used extensively in building. The m'hugu, Brachylaena hutchinsi, a giant member of the Compositae, is largely used for fuel, and for fencing and telegraph poles as white ants do not attack its wood. 
Podocarpus, so far, has no fungous enemies; its timber, however, is very much attacked by termites. Juniperus procera is subject to the attacks of the bracket fungus Fomes juniperinus (Schrenk.) Sacc. \& Syd., which causes very great damage by producing a heart-rot. About 70 per cent. of the trees are affected, and it is quite common to see newly felled trunks with a large part of the wood replaced by spongy red masses extending for considerable distances. Fomes juniperinus is probably a wound parasite, the hoof-like fructifications of which are usually formed just below a small branch which has been broken off a long time previously and which has not been occluded over. The heart wood of Juniperus procera is resistant to the attack of white ants.

Brachylaena hutchinsi, a tall tree with a straight trunk, is often killed by strangulation brought about by the entwining and anastomosing branches of a species of fig. This fig gradually surrounds the trunk of its host and all stages are commonly met with, from the partially grown fig at the base of its victim to the nearly fully matured parasite with its rounded head of foliage, out of which can just be distinguished the topmost branches of the Brachylaena, evidently in extremis. Finally a stage is reached in which the m'hugu rots away leaving the fig standing alone, and soon afterwards the fig itself dies.

Recently, an important Sclerotinia disease of the young seedlings of Brachylaena in the nurseries of the Forestry Department near Nairobi has been recorded and partially investigated. The young trees were found to wither and die when they had reached a height of from 3 to 4 feet. An examination of the roots brought to light numerous small black sclerotia, irregular in shape, clinging to the base of the stem just below ground level. The sclerotia varied in size from a rounded mass $1 \mathrm{~mm}$. in diameter to a flat irregularly shaped mass $1 \mathrm{~cm}$. across. Several specimens of the sclerotia were collected and kept under conditions as natural as possible, and after a few months began to produce apothecia on long ( $\frac{1}{2}$ in.) stalks. None, however, succeeded in reaching maturity, and when nearly fully opened, withered and died down. On investigation these nearly ripe apothecia were discovered to be infested by eelworm, and the question arises as to whether or not in nature the spread of this fungus is kept in check by the eelworm. The investigation could not be completed and the few apothecia produced in the places where the infected trees had been removed likewise succumbed to eelworm attack. 

lady-bird beetle, the larva of which will devour the Icerya and helps to check to some extent the damage caused by this insect. A resin soda spray has been employed with good results against the Aspidiotus, but it is now the endeavour of the Government to destroy all trees infected by the red scale and to replace them with healthy young stock.

\section{Wheat.}

Wheat, like coffee, affords another instance of the variable relations existing between host and parasite under different climatic conditions. For the purpose of the present paper it will prove useful to contrast the relation of the rust fungi to wheat in three widely separated countries such as England, East Africa and Australia. In all three countries the same three rusts attack wheat, namely, the black stem rust (Puccinia graminis Pers.), the yellow rust (Puccinia glumarum Eriks. \& Henn.), and the brown or leaf rust (Puccinia triticina Eriks.). In England Puccinia glumarum is the commonest and most destructive; in Australia Puccinia triticina causes most damage because of its very early appearance in the season, wheat when only a few inches high in New South Wales being attacked. In East Africa the greatest destruction is due to Puccinia graminis, while in addition to this, Puccinia glumarum is very common on certain wheats of Egyptian origin. These two rusts usually, and Puccinia triticina nearly always, appear late in the season, generally after the wheat has come into flower. Hence it will be seen that the problem of controlling rust in wheat in East Africa differs from that in the other two countries mentioned. Climatic conditions also influence very considerably not only the growing of the wheat but also the spread of the rust. Thus at Nairobi there are two rainy seasons in the year, during both of which it is possible to grow early maturing varieties of wheat. The fact that it is necessary to employ varieties which mature early, that is, in four to five months, because of the shortness of the seasons, makes it possible to grow with success such varieties as escape the rust attack on account of this character. As an instance of this, the Australian wheat "Florence" may be cited, which at Nairobi was found to mature in four months after sowing. "Florence" is not a rust resistant variety, but when sown early enough escapes the rust attack. This was demonstrated at the Experimental Farm near Nairobi where, during some of the trials, "Florence" and another Australian wheat, "Bobs," were sown in adjacent plots and at the same time. "Bobs" takes between six and seven months to ripen and always falls a victim to the attacks of Puccinia triticina and Puccinia graminis which make their 
appeared and on searching the soil four months later I found 99 dead maggots. Lack of moisture in the soil is therefore a probable source of loss.

The hoeing up in singling of plants harbouring small maggots must surely be a source of loss, though maggots are able to extricate themselves from plants left lying on soil, and quite small maggots are able to pupate successfully, though, of course, they turn into small flies. But I find that the proportion of small maggots which pupate successfully is lower than the proportion of larger maggots, and that such small flies contain fewer eggs than larger flies although the eggs in both are about the same size.

The Midge has some enemies. An Empid fly which sucks the juices from the flies was common at Garforth in June 1914. Some Midges are accounted for by small spiders. And in September 1914 in some experiments I reared a number of Proctotrypid flies from Swede Midge maggots.

In 1912 in the East Riding the competition of the Turnip Flea Beetle, Phyllotreta nemorum, was a matter of some importance. The Flea Beetle attacks the seed leaves of swede plants while the Midge does not attack them until they get into rough leaf. In 1912 the- Flea Beetle was rampant in the East Riding and often made it necessary to sow two or even three times.

One more conclusion may be drawn from a comparison of the figures for the different years. If it is not already possible it probably would be possible after a few years further work to foretell, roughly, before the first brood makes its appearance, the sort of attack which may be expected. In 1911 the Midge increased enormously in number and the first brood of 1912 was a very large one. In 1912 the numbers of the Midge were greatly reduced and the first brood of 1913 was a very small one. In 1913 the Midge increased in number, but did not make much progress, and the first brood of 1914 was by no means numerous. If it is the weather which is the chief factor responsible for these ups and downs of the Midge, then weather statistics alone for a summer, without actual observations in the field, would probably be enough to enable one to make a more or less accurate prophecy of what sort of attack to expect. Unless winter weather is of much importance, and there has not been a severe winter since I first became interested in the Midge, it would be possible to make this prophecy six or eight months before the first brood appeared. I have already pointed out (p. 96), however, the possible complication which may be introduced 
No. 11 is a selection from the hybrid "Early Rieti" and "Red Fife," and has proved highly resistant to Puccinia graminis in all parts of the country so far tried. The other resulted from the cross "Egyptian No. 3" and "Nut Cut." "Egyptian No. 3 " by itself was found to be very resistant to Puccinia graminis but susceptible to Puccinia glumarum, while the Australian "Nut Cut" was susceptible to Puccinia graminis but resistant to Puccinia glumarum. From the resulting hybrid Cross No. 13 was selected and was found highly resistant to both rusts.

\section{Flax.}

Flax, which grows well in the Highlands, is subject to the attacks of numerous enemies, chief of which at the present time is the cut worm, the larva of certain moths. The loss caused by the depredations of this grub are enormous, whole fields being completely destroyed soon after the plants appear above the ground. Any spray wbich poisons the cut worms also kills the flax, and up to the present no method has been devised of coping with this most destructive pest. As has been noted, newly planted coffee is also very subject to the attentions of these larvae, but in some districts the pest is more prevalent than in others.

The mature flax plant is often attacked by a flax moth which lays its eggs in the ripening capsules so that considerable damage is caused in this way to flax grown for seed.

Of fungous diseases, the wilt caused by Fusarium lini Boll. is the most important and is commencing to spread in certain localities. The appearance of this disease is most probably due to imported seed bearing the conidia of the Fusarium, and its spread is undoubtedly the result of the present practice of growing two or even three crops on the same land without a break or rotation. Experiments designed to prevent the spread of the wilt by infected seed have been commenced, and although of a preliminary nature, have given unexpected results. As flax seed is extremely difficult to disinfect by the usual method of wetting with formalin solution, or with copper sulphate, by reason of its mucilaginous coat, it was thought possible that the desired result might be obtained by subjecting the seed to the action of formalin vapour. The first experiments were designed to find out what effect the action of the gas would have on the germinating power of the seed. Fresh seed from an uninfected area was treated for 4 hours, and the amount of formalin or the number of tablets was to be increased steadily until a marked effect on the germination of the seed was produced. After each experiment 200 seeds were counted out and placed in petri dishes to germinate. The 


\section{Problems of Economic Biology in East Africa}

first two or three times this was done no effect either on the rate or on the amount of germination was apparent, the results showing 98 per cent. germination in 48 hours. Later, however, with a greater concentration of gas, the rate of germination was accelerated, 98 per cent. germination being obtained in 24 hours. This result was quite unlooked for, and is the reverse of what would be expected. The usual result of soaking seed, for instance coffee, in a solution of formalin (over night in a 0.3 per cent. solution) is to retard its germination from one month to anything up to three months according to the age of the seed. The effect of the gas on the Fusarium conidia was not tried owing to the absence of infected material at the time this work was started.

(Received March 8th, 1921.) 